Chase Ollis

\title{
ACRL honors the 2016 award winners, part 1 \\ A recognition of professional development
}

\section{Excellence in Academic Libraries \\ Award winners: Examples of transformation}

The winners of the 2016 Excellence in Academic Libraries Award are the Atlanta University Center Robert W. Woodruff Library (Atlanta, Georgia), Macalester College DeWitt Wallace Library (Saint Paul, Minn e s o t a ), and Hudson County Community College Library (Jersey City, New Jersey). Sponsored by ACRL and YBP Library Services, the award recognizes the staff of a college,

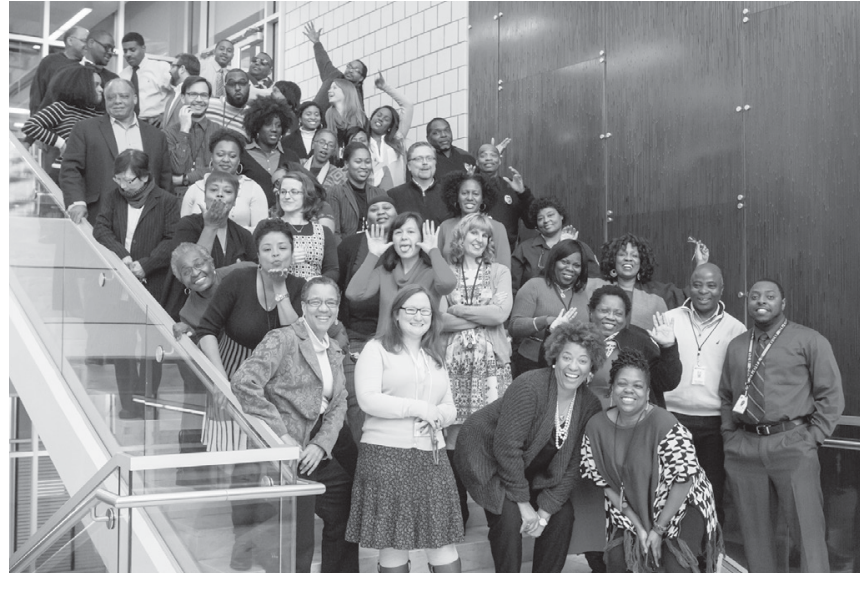

Staff of Atlanta University Center's Robert W. Woodruff Library. rector. "Receiving an Excellence in Academic Libraries Award is a national tribute to each library and its staff for outstanding services, programs, and leadership."

Through transforming services and extensive collaboration efforts, the three winning libraries have made lasting, positive impacts in the lives of the members of their institutions' communities.

Atlanta University Center $\mathrm{N}$ e s t l e d comfortably among a consortium of four prestigious Historically Black Colleges and university, and community college library for programs that deliver exemplary services and resources to further the educational mission of the institution.

"These three deserving recipients demonstrate commitment to student learning, information literacy, and assessment, with a focus on continuous innovation and engagement with the campus community, that exemplifies today's best academic and research libraries," says Mary Ellen K. Davis, ACRL executive di-
Universities in downtown Atlanta stands its beating heart-the Atlanta University Center Robert W. Woodruff Library. Serving the academic communities of Clark Atlanta University, the Interdenominational Theological Center, Morehouse College, and Spelman College, the recently renovated

Chase Ollis is ACRL program coordinator, email: collis@ ala.org

C 2016 Chase Ollis 


\section{Nutter named Academic/Research Librarian of the Year}

Susan K. Nutter, vice provost and director of libraries at North Carolina State University (NCSU), is the 2016 ACRLAcademic/Research Librarian of the Year.The award, sponsored by YBP Library Services, recognizes an outstanding member of the library profession who has made a significant national or international contribution to academic/research librarianship and library development.

Nutter will receive a \$5,000 award during the ACRL President's Program on Saturday, June 26, 2016, at the 2016 ALA Annual Conference in Orlando, Florida.

"Susan defined a vision for the library of the future, and went on to implement it through the physical transformation of the NCSU Libraries, with its pinnacle being the technology-rich and user-centered James B. Hunt, Jr. Library. As one nominator stated, her vision has reinvigorated '...the very idea of a library's centrality to its campus community," said

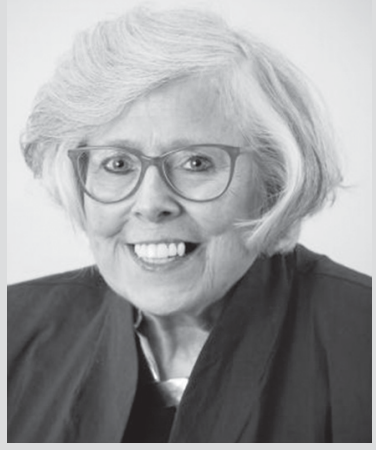

Susan K. Nutter
Excellence in Academic Libraries Award in the university library category in 2000.

Not one to rest on her laurels, Nutter was the driving force behind the planning, development, and construction of NCSU's renowned James B. Hunt,Jr. Library. Opened in January 2013, the Hunt Library is NCSU's second main library, as well as the intellectual and social center of Centennial Campus.Widely praised for its innovative services, technologies, and use of space, the Hunt Library reflects Nutter's longstanding belief that it is the priorities and practices of the university that must shape the spaces and offerings of the library. Due to her efforts, the Hunt Library was awarded the Stanford Prize for Innovation in Research Libraries in 2014 and serves as a model for other institutions looking to develop innovative learning and research spaces.

An active member of ALA and ACRL, Nutter also served as president of the Association of Research Libraries (1993); member (1987-92) and chair (1990-91) of the SOLINET Board of Directors; member (1995-98) and secretary (1996-97) of the Center for Research Libraries Board of Directors; and member of the Digital Library Federation Steering Committee (1998-present).

Nutter's wide array of personal awards includes receiving the Simmons College Graduate School of Library and Information Science Alumni Achievement Award (1995), the Hugh C.Atkinson Memorial Award (1999), and being named Library Journal's Librarian of the Year in 2005. Under her leadership, the NCSU Libraries also received the John Cotton Dana Library Public Relations Award in 1990 and 2014.

Prior to joining NCSU in 1987 , Nutter held various positions at the Massachusetts Institute of Technology Libraries. She additionally served as a Council on Library Resources Academic Library Management Intern at the University of North Carolina-Chapel Hill (1979-80). library in higher education. Under her lea ship, the NCSU Libraries received the first ACRL 


\section{Excellence Award winners by the numbers}

\section{Atlanta University Center Robert W. Woodruff Library}

- Nearly $\mathbf{7 , 8 9 9}$ undergraduate and graduate students served.

- Approximately 653 faculty served.

- Built in 1982, renovated 2010.

- More than 1.5 million items: 364,010 print volumes, 82,075 electronic books, 4,002 current periodical subscriptions, $\mathbf{8 9 , 2 6 2}$ electronic full text journals, $\mathbf{3 0 2}$ databases.

\section{Macalester College DeWitt Wallace Library}

- 2,172 students served.

- 160 faculty served.

- Built in 1988.

- 411,784 volumes, 191 research databases.

\section{Hudson County Community College Library}

- Approximately 10,000 students, faculty, staff, and community members served.

- New facility built in $\mathbf{2 0 1 4}$.

- More than $\mathbf{4 0 , 0 0 0}$ books, $\mathbf{7 5 0}$ DVDs, 37,000 online journals, $\mathbf{2 , 8 0 0}$ ebooks.
It is this innovative thinking that allows the Woodruff library to not only succeed in its efforts in managing services for multiple institutions, but to consistently improve upon itself. Dawes notes, "While many of us are challenged by relationships with one group of administrators, faculty, and students, the Atlanta University Center manages to effectively support the teaching, learning, and research at four different institutions, deftly managing those relationships. The library has made a huge turnaround in services and programs, using assessment and data as an important component of their continuous improvement process."

The Woodruff Library has used this turnaround to not only improve itself, but to engage with both the collegiate and local community, hosting a variety of events, including block parties, traveling art exhibits, lectures, book signings, and conferences-all of which are open to the public.

"To be recognized for our demonstrated dedication to excellence and professional services is a validation of the collective efforts of a great library team," says Loretta Parham, CEO and director of the Woodruff Library. "As a single library that is shared by the academic members of the Atlanta University Center Consortium, we are honored to work in support of student and faculty success and cultural preservation."

The Woodruff Library staff hopes to build on their momentum, embracing new resources to contribute to the library's excellence.

\section{Macalester College}

Recognized as "truly one of the jewels of the institution," the DeWitt Wallace Library at Macalester College rests among tree-lined sidewalks at the center of its Saint Paul, Minnesota, campus. Inside, however, the library bustles with activity, led by a staff driven by 
the vision of "enhancing the transformational experience of a Macalester education."

The staff at the Wallace Library have many accomplishments to be proud of, be it assessment initiatives to better serve and impact the campus community, its instruction and information fluency programs, or its open access and fair use efforts, to name a few. But a central theme resonates from the library's core identity: collaboration.

"The DeWitt Wallace Library's variety of collaborative relationships,

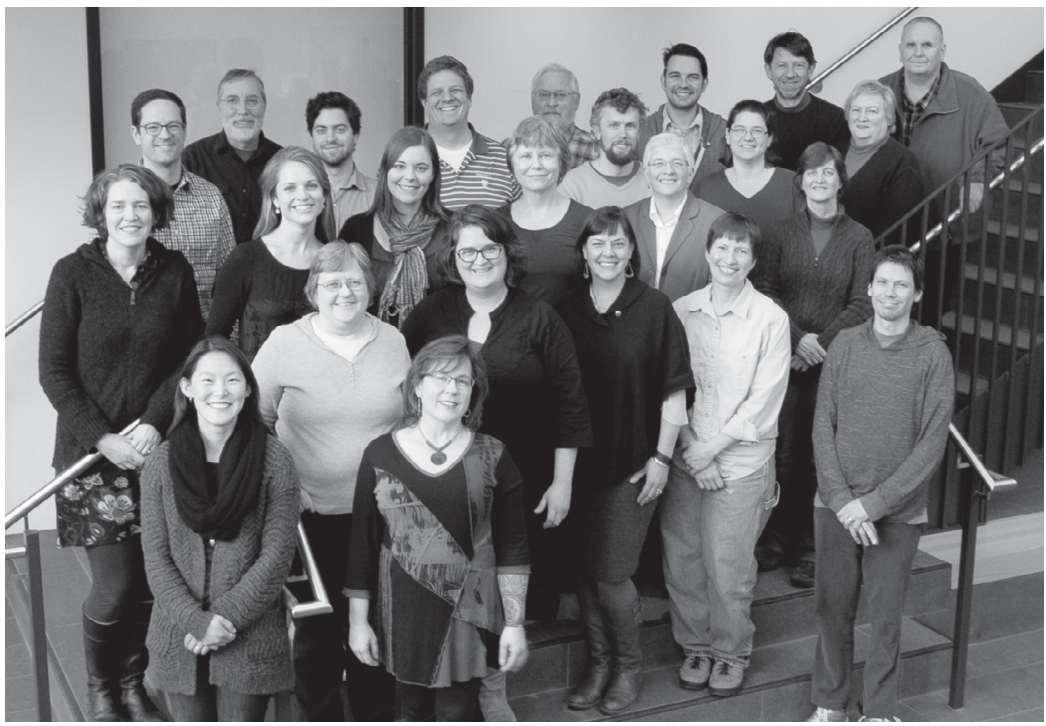

Staff of Macalester College's DeWitt Wallace Library. Photograph by Baxtercreek Photography.

such as those with IT and the Center for Scholarship and Teaching, among many others both on and off campus, was quite noteworthy," says Dawes. Indeed, the Wallace Library's collaboration efforts with the campus community and beyond have served as a powerful engine to foster student success and diversity, helping to align the library's goals with Macalester's emphasis on internationalism, multiculturalism, and service to society.

"The library's partnership with AdvanceIT Minnesota to encourage greater female participation in STEM fields is to be commended," Dawes continues. "The program goals are to increase 'the diversity of the future Information Technology workforce, to empower girls to engage in STEM education and fields, to bring higher education and college to the forefront for those who may need that exposure, and to create a community among girls and young women as they prepare for college and the workforce."”
This collaboration is exemplified even more through its newly designed single point service approach, and the flexible, multitalented staff that command it. And by turning outward from a single service point, the library staff has effectively worked to eliminate the "ping-pong" effect patrons feel from multiple service points, and to break down outdated knowledge silos.

"I have the pleasure of working with extremely talented, creative, and dedicated people," says Terri Fishel, library director at Macalester College. "Each and every one contributes so much every day. I am delighted to have their work recognized by receiving this distinguished award."

Through its collaborative efforts, the Wallace Library has committed to responding to the ever-changing and evolving nature of the field.

\section{Hudson County Community College}

Transformation is a key ingredient to the newly constructed Hudson County Community College (HCCC) library, which serves a diverse community of nearly 10,000 students, faculty, staff, and community members of Jersey City. Last year, the library moved from its old location to a new, state-of-the-art 
facility—a perfect jumping off point for adding a host of new programs and services, such as an iPad circulation cart, and one of the first academic library makerspaces in the country, which hosts an abundance of programs, including jewelry making, genealogy, photo editing, and more.

"The library has demonstrated technology leadership across the campuses through the use of various services, such as the iPad cart and the makerspace," says Dawes. "The solutions to meet campus needs are both hightech and low-tech, based on the needs of the constituents."

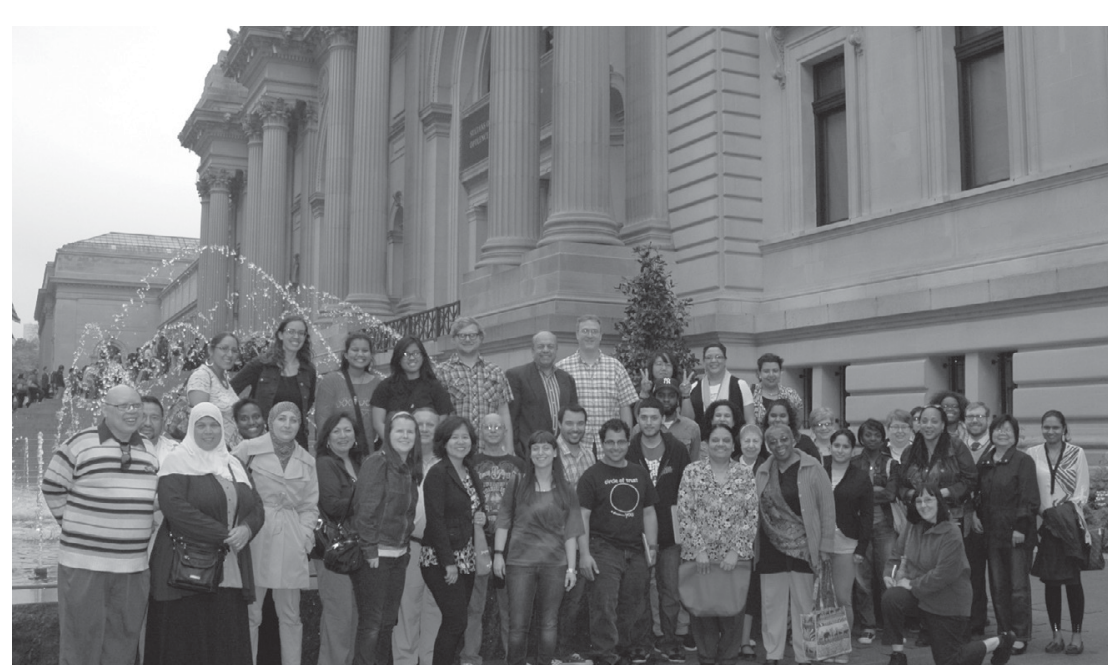

Staff of Hudson County Community College's library. ing staff, whose campus engagement efforts have strengthened the library's relationship with the community.

"HCCC Library staff demonstrated a clear focus on students through their active social media outreach, inclusion of students on their advisory board, and various other collaborative efforts in which students are involved," says Dawes. Nine library staff members also serve on the All College Council-the campus governance body-which is more than any other department on campus, and have increased collaboration efforts with the Student Affairs division to host several
The HCCC library's transformation has allowed its other services to excel around campus, especially in its bibliographic instruction initiatives. As Dawes notes, "The library staff has done an impressive job at incorporating information literacy components across all General Education courses, resulting in a positive impact on student learning." Additionally, the library's new space has afforded it the opportunity to add a dedicated instruction room, from which it has already expanded outside of with a variety of informational workshops on career resources, citation management, STEM resources, and more.

At the heart of the HCCC library's transformation, though, is a creative and engag- who truly care about our students," says Carol Van Houten, associate dean for college libraries at HCCC. "We are so happy to be recognized as an outstanding community college library!"

The HCCC library plans to continue its development in programs during spring 2016 and beyond, working to expand its already successful programs, and adding others focused on training, archives digitization, and assessment initiatives.

Winners are selected by the ACRL Excellence in Academic Libraries Award Committee. Each winning library will receive $\$ 3,000$ and a plaque, donated by YBP Library Services, to be presented at an award ceremony held on each recipient's campus. Additional 
information on the Excellence in Academic Libraries Award, including a list of past winners and digital copies of winning applications, is available on the ACRL website at www. ala.org/acrl/awards/achievementawards /excellenceacademic.

\section{Merolli receives CLS Innovation in College Librarianship Award}

Barbara Merolli, science librarian at the College of the Holy Cross, has been named

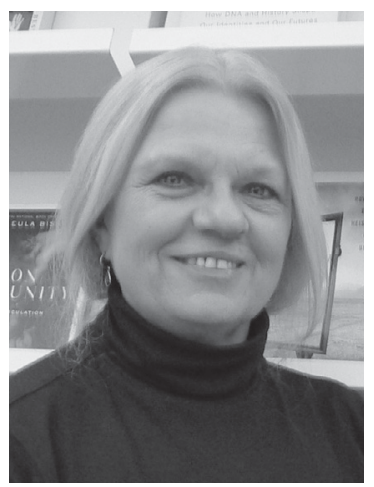

Barbara Merolli the recipient of ACRL's College Libraries Section (CLS) Innovation in College Librarianship Award for her work on the "Drawing on Walls" program.

This annual award honors ALA members who have demonstrated a capacity for innovation in their work with undergraduates, instructors, and/ or the library community.

Merolli's \$1,000 award and plaque, donated by CLS, will be presented during the CLS program at the 2016 ALA Annual Conference.

"Drawing on Walls" was a collaboration between Merolli and Visual Arts Visiting Lecturer Marguerite White during the spring semester 2015 at the College of the Holy Cross, in which students in White's "Drawing on Walls" class used the stark white walls of the O'Callahan Science Library to create their final projects. The project's impact has attracted a large increase of nontraditional users to the library.

"The committee was impressed with Merolli's project for crossing disciplines and drawing undergraduate users into the science library in a way that was replicable across a number of different types of libraries," said award Chair Leah Dunn, university librarian at the University of North CarolinaAsheville.

\section{Collins, Kearns, and Pitts win IS Innovation Award}

Heather Collins, Sara Kearns, and Joelle Pitts have been selected to receive the ACRL Instruction Section (IS) Innovation award for their work on the New Literacies Alliance (NLA) project, an online platform that addresses the "new" literacies required for academic success and lifelong learning and that allows stu-

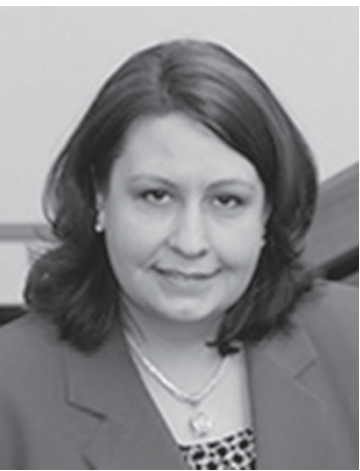

Heather Collins dents to master skills at their own pace. Collins is the assistant director of research and learning at the University of Kansas Medical Center Dykes Library, Kearns is the head of undergraduate/ community services at Kansas State University's Hale Library, and Pitts is instructional design librarian

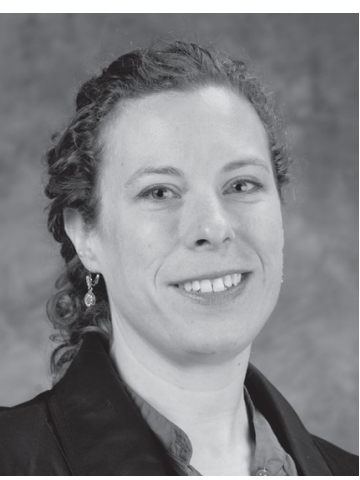

Sara Kearns at Kansas State University's Hale Library.

The annual award recognizes a project that demonstrates creative, innovative, or unique approaches to information literacy instruction or programming. The plaque and $\$ 3,000$ award, donated by

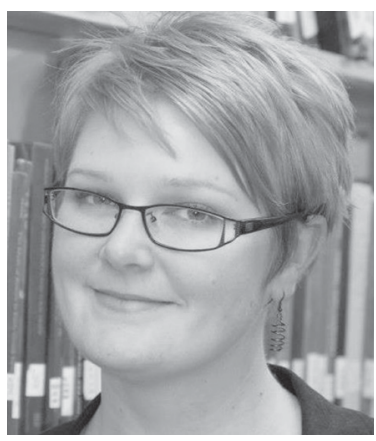

Joelle Pitts 
EBSCO, will be presented to the group at the ALA Annual Conference.

"The New Literacies Alliance project was chosen due to its focus on transferrable skills and usefulness to students in the health professions," said award committee Chair Elana D. Karshmer of Saint Leo University. "While many of the projects considered were interesting and innovative, they did not combine theoretical learning and skills-based practice to the extent that the New Literacies Alliance did; the project was well designed, well executed, and most importantly, easy to implement in a variety of educational settings."

NLA is a consortial project to create interactive online lessons addressing basic concepts of information and related literacies using an accessible interface that retains student scores on lesson activities and assessments. Librarians and instructors can expand on these concepts in classes through active learning or explore discipline-specific aspects of literacy practices. Lessons are platform and institution agnostic, focusing on knowledge practices rather than specific databases or institutional websites.

Student scores are retained in order to create a record of a student's completion of lessons. These scores can be shared with instructors in future classes the student may enroll in and even, ideally, with instructors at partner institutions should the student transfer, obviating the need for a student to complete the same lessons for multiple classes.

The project is led by librarians from Kansas State University and the University of Kansas Medical Center. Partner institutions currently include Fort Hays State University, Indiana University, Marquette University, and, most recently, Oklahoma State University.

\section{Kahl named Marta Lange/SAGE-CQ Press Award winner}

Chad Kahl, interim associate dean for public services and information technology at Illinois State University, has been awarded the ACRL Law and Political Science Section (LPSS) Marta Lange/SAGE-CQ Press Award. The award, established in 1996 by LPSS, honors an academic or law librarian who has made distinguished contributions to bibliography and information service in law or political science.

SAGE-CQ Press, sponsor of the award, will present the $\$ 1,000$ award and plaque to Kahl during the ALA Annual Conference.

"Chad's extensive contributions to legal and political science librarianship spans from service to scholarship, continually demonstrat-

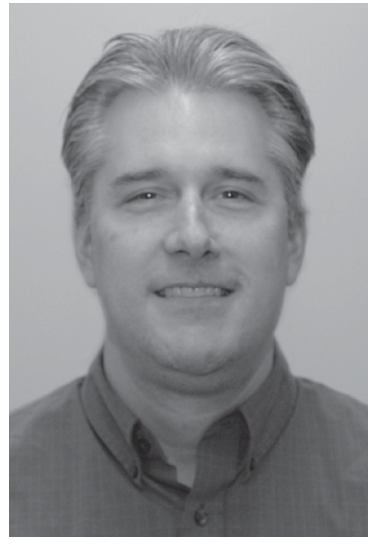

Chad Kahl ing his knowledge of the field, and passion for civic engagement," said award Chair Mary K. Oberlies, Conflict and Peace Studies librarian at George Mason University. "He has played an active role in the Law and Political Science section of ACRL, having served on numerous committees, and as the section chair, vicechair/chair-elect, and past chair. Within LPSS he has developed the strategic direction of the section, assisted with programming, and spearheaded efforts to resurrect the Statistical Resources on the Web guide."

"Professionally, Chad has worked to create a politically engaged campus at Illinois State University, serving on the task force to create a Center for Civic Engagement, and chairing the Political Engagement Project Coordinating Council," Oberlies continued. "His scholarship also highlights his contributions to the legal and political science librarianship with publications and presentations that focus on the intersection of libraries and government, including his chapter in Privacy in the Digital Age, 'Library Patrons and the National Security State.' His bibliographic reference source International Relations, International Security, and Comparative Politics: A Guide to Reference and Information Services is widely held within libraries as an invaluable reference source for political science and international relations." 


\section{Pagowsky receives inaugural ULS Outstanding Professional Development Award}

Nicole Pagowsky, research and learning librarian/instruction coordinator at the University of Arizona, has been chosen to receive the ACRL University Libraries Section (ULS) Outstanding Professional Development Award.

The $\$ 1,000$ award and plaque, donated

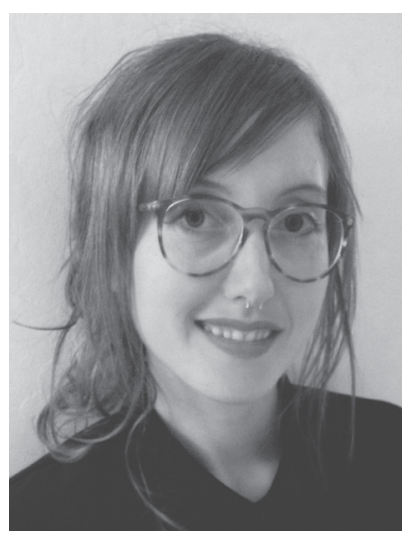

Nicole Pagowsky by Library Juice Academy, will be presented to Pagowsky at the ALA Annual Conference.

"Though early in her career, Nicole Pagowsky has made a significant impact to academic librarianship through broad professional engagement, scholarship, and service," said award Chair Rebecca Blakiston of the University of Arizona. "In addition to being active in social media and professional blogging, Nicole has already coedited two books, taught an ALA eCourse, presented an ACRL webinar, created the ACRL student retention Discussion Group, presented as a keynote speaker at a state library conference, initiated \#critlib chats, and organized the first Critical Librarianship and Pedagogy Symposium. She has initiated and provided innovative opportunities for the professional growth of librarians nationwide. As librarianship continues to advance, it is library leaders such as Nicole Pagowsky who act as proactive agents of change and provide the necessary support for successful information professionals."

\section{Figueroa named WESS-SEES De Gruyter Grant winner}

Patricia Figueroa, curator of the Iberian and Latin American Collection at Brown Univer- sity, has been selected to receive the ACRL Western European Studies Section (WESS)/ Slavic and East European Section (SEES) De Gruyter European Librarianship Study Grant for her project, "Voices from La Movida: Indexing Spain's Underground Magazines from the Transition Period."

Sponsored by the Walter de Gruyter Foundation for Scholarship and Re-

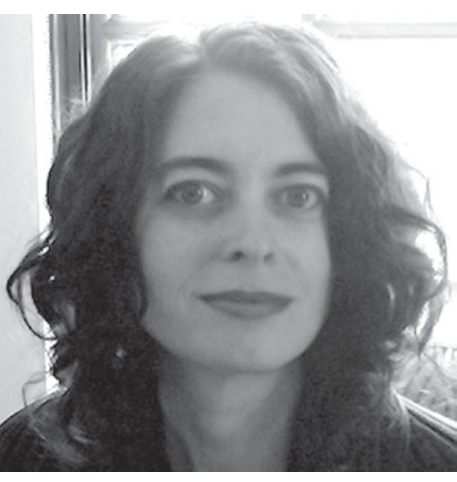

Patricia Figueroa search,

the grant provides $€ 2,500$ to support a trip to Europe. The primary criterion for awarding the grant is the significance and utility of the proposed project as a contribution to the study of the acquisition, organization, or use of library resources from or relating to Europe.

Figueroa will receive the award check at the ALA Annual Conference.

Figueroa's project will focus on magazines from the Spanish Transition Period known as La Movida, a countercultural movement that emerged soon after the death of Francisco Franco that spans from 1976 through 1989, in order to create a comprehensive index of the magazines with pertinent metadata. This research will result in an open access database, where researchers will be able to find citations and metadata for articles, comic strips, and reviews published in five different Spanish magazines from this period.

"Among the proposals, the committee thought this project best fulfilled the selection criteria, was particularly well-conceived, and would result in a useful resource for librarians and scholars working on the La Movida cultural movement," said award Chair Sarah Sussman of Stanford University. $\boldsymbol{n}$ 